\title{
THE NEW FEDERAL ATTACK ON THE LOAN SHARK PROBLEM
}

\author{
Walter D. Malcolm* and John J. Curtin, Jr. $\dagger$
}

\section{Background of the Problem}

At a time when a presidential candidate makes an attack on loan sharking such a significant part of his campaign that it is highlighted in his acceptance speech and rebroadcast as part of one-minute spot political announcements, the timeliness of this subject is apparent. ${ }^{1}$ This high-level attention illustrates growing public awareness of the very serious nature of the loan shark problem. In recent years a number of investigations of loan sharking have been undertaken by governmental agencies and other entities. Their conclusions are striking. Loan sharking has been characterized as "a serious threat, not only to the unfortunate borrowers but also to the entire economic community" and as "one of the principal and most lucrative operations of the criminal underworld."2 The seriousness of the problem is accentuated because loan sharking has close connections with other activities of organized crime, including bookmaking and narcotics distribution." "Pushers" loan money to addicts to finance drug purchases. Money lenders frequent gambling establishments to offer services to overenthusiastic patrons who want one more chance. ${ }^{5}$

In this setting the Congress of the United States chose in Ig68 to make what it termed "extortionate credit transactions" a federal crime and did so as Title II of the more general legislation concerning certain aspects of consumer credit entitled the Consumer Credit Protection Act of I968 (CCPA). ${ }^{\circ}$ The importance attached by the Congress to the enactment of these provisions is reflected in the conference report's express statement that this was "a deliberate legislative attack on the economic foundations of organized crime." On the floor of the House, Congress-

* B.S. I926, University of Oregon; LL.B. I929, Harvard University. Member of the Massachusetts and Oregon bars; Partner, Bingham, Dana \& Gould, Boston, Mass. Massachusetts Commissioner on Uniform State Laws and former President, National Conference of Commissioners on Uniform State Laws; Member, Drafting Committee for the Uniform Consumer Credit Code.

† A.B. 1954, IL.B. 1957, Boston College; LI.M. I959, Georgetown University. Member of the Massachusetts and District of Columbia bars; Partner, Bingham, Dana \& Gould, Boston, Mass.

${ }^{1}$ Speech of Richard Nixon accepting the nomination of the Republican Party for President of the United States, N.Y. Times, Aug. 9, I968, at I, col. 3, transcript at 20.

${ }^{2}$ New York Temporary Commisston of Investigation, 7t7 ANN. ReP. 56, 57 (Ig65).

${ }^{3} I d$. at $6 \mathrm{I}$.

Id.

"Hearings on Impact of Crime on Small Business Before the Senate Select Comm. on Small Business, 90th Cong., 2d Sess. 127 (1968) [hereinafter cited as Senate Hearings].

${ }^{\circ} 82$ Stat. 146 (rg68) [hereinafter cited as CCPA].

${ }^{7}$ H.R. Rep. No. I397, 90th Cong., 2d Sess. $3 \mathrm{I}$ (I968) [hereinafter cited as Conference ReporT]. 
man McDade of Texas commented that an early version of the provisions prohibiting extortionate credit transactions involved recognition for the first time on the federal level of "the difference between organized crime and other types of crime." The underlying predicate of this attack is the express congressional finding that "a substantial part of the income of organized crime is generated by extortionate credit transactions."

A preliminary definition of the target of this congressional firepower is appropriate. Loan sharking has sometimes been considered solely in terms of the interest rates charged for the use of money. For example, the report of a New York State commission in 1965 defined it as "the charge of unconscionably high and onerous rates of interest on loans of money." 10 Congress, following extensive hearings, did not attack loan sharking as so defined. The federal crime relates to "extortionate credit transactions," 11 and the act recites express congressional findings that "extortionate credit transactions are characterized by the use, or the express or implicit threat of the use, of violence or other criminal means to cause harm to person, reputation, or property as a means of enforcing repayment." ${ }^{\text {"2 }}$ The general approach of the CCPA is to define extortionate credit transactions in terms of this express finding and to provide a nonexclusive method of proof of the violation which is only partially satisfied by proof that an excessive rate of interest, as defined, was charged. ${ }^{13}$ The statutory definitions will be discussed more fully hereafter, but this approach insures that Title II is not a federal usury law but a congressional attack on organized crime and particularly the top levels-"the organizers and financiers of the underworld." 14

Law enforcement officials consider that loan sharking has been successfully used by organized crime through existing underworld organizational structures. ${ }^{16}$ There are three principal echelons above the ultimate customer. On the top level is the underworld boss who is the original source of money. Large sums are entrusted to chief lieutenants and under-bosses on the second echelon. A customary rate of interest by the first to the second echelon is payment of $\mathrm{I}$ per cent "vigorish" weekly. ${ }^{16}$ It should be noted that no excuses for failure of performance are accepted. These chief subordinates act as middlemen and loan moneys to the third echelon, which deals with the ultimate borrower. Rates to this third level may

\footnotetext{
${ }^{8}$ Ir4 Cong. REc. H630 (daily ed. Jan. 3I, I968).

${ }^{\circ}$ CCPA $\$ 201(a)(\mathrm{I})$.

${ }^{10}$ New York State Commission of Investigation, The Loan Shark Racket 7 (1965). See also statement of Henry Peterson in' Senate Hearings $3 \mathrm{I}$.

${ }^{11}$ Conference Report 30. The Conference Report notes that the act adds a weapon whereby "loan sharks at the operating level" may be prosecuted. Id.

${ }^{12}$ CCPA $\$ 20 I(a)(2)$.

${ }^{13}$ CONFERENCE RePort 30.

It Id.

${ }^{15} \mathrm{New}$ York Temporary Commission of Investigation, supta note 2, at 57.

${ }^{10}$ Vigorish is the underworld term for interest and other penalties for charges imposed on a loan. Id. at 58 .
} 
range from $1^{1} / 2$ per cent to $2 \frac{1}{2}$ per cent weekly while the ultimate borrowers pays interest at rates usually not less than 5 per cent per week. ${ }^{17}$

While this organizational structure may not be too meaningful to the ultimate borrower dealing with the third echelon, the language of the congressional findings cannot obscure the bald fact that the security in loan sharking is the body of the borrower. Bodily harm is always a possibility, and the threat of harm to the borrower and to his family is a normal collection tool. ${ }^{18}$

Loan sharking is not limited to the poor and the ghetto. In recent years businessmen unable to pay their debts have lost their businesses to the loan shark. A spokesman for the Justice Department concluded that more and more individuals engaged in organized crime are looking into loan sharking because they feel themselves relatively safe from prosecution on either the federal or the state level. ${ }^{19}$ With this background, this article will consider the prior applicable law, the relevant provisions, substantive and procedural, of Title II of the CCPA, and related provisions of the Uniform Consumer Credit Code (UCCC) ${ }^{20}$ and will analyze the effect of these statutes on organized crime and the public at large.

II

\section{Prior Applicable Law}

As developed in the CCPA, there are two basic elements to loan sharking, namely, the lending of money at exorbitant rates of interest and the collection of principal and interest by the nonlegal means of murder, assault, blackmail, defamation of character, and the fear engendered by these techniques. Each of these two elements by itself involves a large body of law. Before discussing the CCPA treatment of the subject, it is worthwhile to scan briefly the prior law for each of the two elements.

\section{A. Maximum Interest Rates-Usury}

The charging of exorbitant rates of interest for the loan of money and efforts to prohibit or curb this practice are almost as old as civilization itself. Traditional nomenclature for the subject in general has been usury. Some books and a considerable number of articles have been written on the general subject of usury, but for present purposes Professor Benfield's recent excellent analysis and review of the subject, including a summary of past and existing laws dealing with usury and a discussion of the treatment of maximum rates in the UCCC, ${ }^{21}$ will adequately serve as a reference point.

\footnotetext{
${ }^{17}$ This description of the typical organization is based on $i d$.

${ }^{18} \mathrm{New}$ York State Conmission of Investigation, supra note io, at 28.

${ }^{10}$ See, Senate Hearings 28, 31-32.

${ }^{20}$ On the text of the Code [hereinafter cited as UCCC], see Foreword, in this symposium, p. 639 n.I.

${ }^{21}$ Benfield, Money, Mortgages and Migraine-the Usury Headache, Ig CAsE W. Res. L. Rev. 8I9 (1968). See also B. Curran, Recent Trends in Consumer Credit Legislation (i965).
} 
A review of Professor Benfield's article and its appendices furnishes eloquent evidence that existing state and federal laws dealing with interest rates and similar charges for the cost of money or credit present a picture of magnificent confusion and uncertainty. Looking beneath the surface of actual statutes and case law on the subject, it is not surprising that this is the case. Underlying currents of thinking and history leading to the present state of affairs include the first attempts of early societies to deal with the subject; biblical injunctions against lending at interest and efforts of the church-oriented society of the Middle Ages to observe these biblical injunctions; the needs of trade and commerce during the eleventh through fourteenth centuries to expand and obtain financing and break out of the inhibitions of the Middle Ages; the efforts of the American colonies, commencing as early as I64x, to deal with this general problem with the first simple general usury statutes permitting the charging of interest but imposing flat 6 per cent or 8 per cent cent per annum ceilings on these charges; the spread of these general usury statutes throughout substantially all of the colonies and states of the United States from I64I to the present time; and finally the recognition in the last half of the nineteenth and through all of the twentieth century that flat, general usury statutes of 6 per cent or 8 per cent per annum simply would not permit many types of legitimate and desirable financing, with the resulting development of exception after exception to the general usury statutes so that today more outstanding private debt is not subject to general usury statutes than is subject. ${ }^{22}$

Professor Benfield notes, and the UCCC recognizes, both the different historical and practical background of sales credit as distinguished from loan credit and the underlying functional parallels between the two. ${ }^{23}$ For present purposes, the timeprice doctrine applicable to sales credit constitutes a major exception to the applicability of general usury statutes, ${ }^{24}$ but to date it has not had appreciable significance in loan sharking and therefore need not be discussed further in this article. In the area of loans, however, the variation in different types of statutes purporting to deal with maximum interest rates or finance charges is almost as great as one might find in any area of the law.

All states except two, Massachusetts and New Hampshire, have general usury statutes or constitutional provisions fixing a general maximum interest rate. Within all but two of the remaining forty-eight states, the District of Columbia, and Puerto Rico, the maximum rate ranges with fairly even distribution from 6 to 12 per cent. ${ }^{25}$ Penalties for violation of these general usury statutes vary almost as much as the prescribed maximum rates, but in general and with some notable exception, states

\footnotetext{
22 Benfield, supra note $2 \mathrm{r}$, at 853-54.

${ }^{23}$ Id. at $843-47$; UCCC arts. 2,3 .

24 Benfield, supra note $2 \mathrm{I}$, at $843-47$.

${ }^{25}$ See id., nn.63-70. Maine and Rhode Island have ceiling rates of $16 \%$ and $21 \%$ respectively.
} 
having lower interest ceilings impose less drastic penalties for violation. Professor Benfield summarizes the applicable sanctions as follows: ${ }^{26}$

In five of the ten 6 percent States, the only penalty for usury is loss of the excess interest over 6 percent. In three others the penalty is loss of all interest. And in Vermont, the penalty is all interest plus one-half of the principal. In straight-laced New York, usury makes the contract void. It appears, therefore, that in onehalf of the 6 percent States the sting of the usury laws is very slight indeed. In only two of the 6 percent States is usury a criminal offense. (A recent New York statute aimed at Mafia-type loans makes it a felony to lend at rates above 25 percent.)

One of the six 7 percent States forfeits the excess over 6 percent for usury; three forfeit all interest; Iowa forfeits all interest plus 16 percent of the principal; and in North Dakota all interest plus 25 percent of principal is forfeited. Two of these States makes usury a misdemeanor.

Of the thirteen 8 percent jurisdictions, two, Missouri and Ohio, penalize usury by forfeiture of the excess interest, and one, Indiana, forfeits the excess above 6 percent. Eight jurisdictions forfeit all interest, while Idaho forfeits treble interest, and Minnesota makes the contract void. Only South Dakota of this group makes usury a misdemeanor.

Nebraska, the single 9 percent State, requires forfeiture of all interest for a violation of the usury law. Four of the ten percent States forfeit all interest, and another three forfeit twice the interest. Kansas requires forfeiture of double the excess over ro percent. Arkansas forfeits all interest and principal, and Oregon, in a complicated scheme, forfeits the loan, less interest and payments on principal, to the school fund.

Of the I2 percent States, Nevada forfeits the excess over 12 percent; Colorado forfeits treble the excess charge; Hawaii and Washington require forfeiture of all interest plus principal under \$2,000; and in Connecticut the entire principal and interest is forfeited. Four of these States make usury a misdemeanor.

New Mexico, a I0-12 percent State, forfeits all interest and makes usury a misdemeanor. Maine, a 16 percent State, forfeits all interest and principal, while Rhode Island forfeits all interest and principal for violation of its 2 I percent limitation and makes violation a misdemeanor.

This discussion has application below, where it is noted that enforceability of the debt under state law becomes an issue under the CCPA.

Because the low-rate general usury statutes simply made impossible the extension of small loans to necessitous borrowers on any reasonably profitable basis, the Uniform Small Loan Law was developed between Igo7 and I9I6 under the sponsorship of the Russell Sage Foundation and was enacted in various versions in numerous states in the ensuing years. Under this proposal, interest rates were to be fixed at realistic levels, originally $3^{1 / 2}$ per cent per month on the smallest loans, and small loan lenders were required to be licensed and supervised; criminal penalties were provided for violations. ${ }^{27}$ Variations in the uniform law's terms occurred in the original enactments or by amendment in the various states so that uniformity

\footnotetext{
${ }^{20}$ Benfield, supra note $2 \mathrm{I}$, at $836-38$ [footnotes omitted].

${ }^{27} \mathrm{Id}$. at 840 .
} 
was never achieved or even approached, but all of the states except Arkansas today have legislation permitting small loans at rates higher than general usury rates.

The widespread variations in small loan legislation include differences in the maximum dollar amount of a loan that can claim the benefit of the usury exemption. The maximum small loan ranges from \$100 to $\$ 7500$, with about two-thirds of the states in the $\$ 300-\$ 1000$ range. ${ }^{28}$ Similar variations also appear in the maximum permissible interest rates, which range on an annual basis from 6 to 60 per cent with thirty states in the 30 to $3^{6}$ per cent range. ${ }^{29}$

Another type of exception which has grown up in response to the undue strictures of general usury statutes is provided in industrial and instalment loan laws, under which industrial banks (formerly Morris Plan banks) and commercial banks may make loans in certain amounts for interest rates higher than those permitted by general usury statutes. ${ }^{30}$ Forty-one states or jurisdictions have laws of this general type, but here again there is substantial variation in dollar jurisdictional amounts that may be loaned and in the maximum rates that may be charged.

In more recent years, with general usury statutes casting their customary inhibitions or prohibitions upon new and old types of financing, some new statutes have been enacted. In six states, special statutes have been passed authorizing banks to charge higher rates-in five states I2 per cent per annum and in one state 8 per cent per annum-plus some per check charge on revolving credit or check-credit loans. ${ }^{31}$ New York has passed another type of revolving credit statute permitting banks to charge 18 per cent per annum in credit card operations. ${ }^{32}$

Under federal law there is no existing general usury statute. However, maximum ceiling rates are imposed on the rate of interest that may be charged by various types of federal lending institutions. Without attempting to list all of these maximum rates, we may note that national banks may charge I per cent in excess of the Federal Reserve discount rate or at the rate allowed by the state where the bank is located, whichever is greater; ${ }^{33}$ federal credit unions may charge interest at the rate of 12 per cent per annum; ${ }^{34}$ federal land banks may make mortgage loans at a rate set by the creditors and approved by the Farm Credit Administration, ${ }^{35}$ and other loans at a rate of $1 / 2$ of I per cent per annum in excess of the rate charged on mortgage loans; ${ }^{36}$ federal home loan banks may charge 8 per cent per annum or the lawful contract rate applicable to the type of transaction involved (presumably

\footnotetext{
${ }^{28}$ See id., app. A.

${ }^{20} \mathrm{Id}$.

${ }^{80} I d$. at $840-43$.

${ }^{81}$ Arizona, New Jersey, New York, Pennsylvania, Texas, and Virginia.

${ }^{82}$ New York Personal Property Law $\$ \$ 4 \times 3$ (3), (II) (McKinney Supp. 1968).

${ }^{88} 12$ U.S.C. $\$ 85(1964)$.

${ }^{34}$ Id. $\$ 7757$.

${ }^{85} I d$. $\$ 77 \mathrm{I}$.

${ }^{86}$ Id. $\$ 723$.
} 
the rate allowed by the state whose law applies to the transaction), whichever is greater; $;^{37}$ and lenders on mortgages insured under the Federal Housing Act may charge interest at such rate as may be prescribed by the Secretary of Housing and Urban Development. ${ }^{38}$ What federal laws there are obviously are highly spotty and limited in application to particular types of institutions and transactions and do not serve appreciably to ameliorate state-imposed strictures on consumer credit.

Thus, it appears that if loan sharking is recognized for what it is, namely, the charging of exorbitant rates of interest by organized crime, the great multiplicity of statutes controlling or affecting the interest rates that may be charged for particular sizes of loans, and prescribing the penalties applicable to overcharges, in and of itself provides substantial aid and comfort to organized crime in its lending activities. The difficulty or impossibility of knowing with definiteness or certainty what maximum rates may be charged; the mildness of the penalties in most cases for overcharges; the prosecutor's difficulty in developing or proving the applicable facts in any case; and the corresponding ease with which operators of organized crime may evade and avoid serious prosecutions and convictions-all provide almost an ideal legal setting or environment, so far as maximum charges are concerned, for loan sharking operations by organized crime.

\section{B. Laws Relating to Violence and Extortion}

Congress, in enacting the CCPA, expressly found that violence or other criminal means to cause harm to person, reputation, and property are used as a means of enforcing payment of extortionate loans, and defined the federal crime in those terms. ${ }^{39}$ Criminal means, by definition, are crimes independent of their connection with loans. Murder and assault are, of course, well-known common law crimes subdivided by statute into violations of differing degrees in many states. ${ }^{40}$ The crime of extortion has been expanded by statute in many states to include the obtaining of any money, property, or thing of value from any person by means of force, fear, or threat. ${ }^{41}$ Such crimes, of course, have traditionally been left to the states for enforcement except for the District of Columbia and federal reservations. ${ }^{42}$ The increase in loan sharking activity described above indicated that statutes directed solely at means of enforcing repayment of loans which reach the level of assault or extortion are inadequate to solve the problem of sponsorship of this activity by organized crime. Testimony at the congressional hearings demonstrated that on either the city or state level there had been little enforcement directed exclusively

\footnotetext{
${ }^{37} I d . \$ r_{425}$.

${ }^{38}$ Id. 1 I $70 \mathrm{Il}$.

${ }^{\circ 0} \mathrm{CCPA} \S 89 \mathrm{I}$.

10 R. Anderson, Wharton's Criminal Law and Procedure $\$ \S$ I87, 329 (I957).

12 Id. $\$ 1396$. Sometimes this offense with some refinement in definition is described as blackmail when committed by a private person.

${ }^{2}$ See, e.g., I8 U.S.C. $\$ 7(3)(1964)$.
} 
to organized crime, although some start had been made, particularly in the New England area. ${ }^{43}$ This is hardly surprising in view of the overlap of city, state, and even county jurisdiction, with traditions of jealously guarded independence. An even more serious obstacle to effective enforcement is that the assault and extortion statutes will usually reach only the low echelon hoodlum who went too far, rather than striking at the heart of the structure of organized crime.

Federal criminal law has previously dealt with extortion, particularly as practiced by organized criminal elements. The Hobbs Act, as amended, makes it a crime to obstruct, delay, or affect interstate commerce by robbery or extortion as defined therein, and it makes the threat or commission of physical violence to any person or property in furtherance of a plan to so affect interstate commerce a federal felony punishable by a $\$ 10,000$ fine or twenty years in prison or both. ${ }^{44}$ The power of Congress to deal with extortion or attempted extortion which actually or potentially affects interstate commerce has been upheld by the courts by analogy to the power of Congress to regulate unfair labor practices affecting interstate commerce. ${ }^{45} \mathrm{Ex}$ tortion is defined in the Hobbs Act to require the obtaining of money or property from the victim, with his consent, and property is very broadly construed..$^{40} \mathrm{~A}$ second element of the offense requires that the property be obtained, or that there be an intent to obtain the property, by fear of violence or threats thereof. The fear, of course, refers to the state of mind of the victim, but it has to be at least objectively reasonable and to have been instilled in the victim by the defendant to induce consent to delivery of the property extorted by some prior demand or proposal of which the accused had knowledge. ${ }^{47}$ Difficulties of proof are obvious, even under this statute. Fear could be established by the testimony of the victim as to his state of mind. ${ }^{48}$

In the opinion of those responsible for their enforcement, these statutes have been inadequate to prevent the increase in loan sharking previously discussed. ${ }^{40} \mathrm{~A}$ major difficulty is the reluctance of victims to testify. Ample evidence was offered of the genuine fear of victims as to the consequences of nonpayment, and the Conference Report expressly noted that such victims "are apt to be equally or even more in fear of the consequences of testifying as a complaining witness."

\footnotetext{
18 Senate Hearings 23.

"1 I8 U.S.C. \$195I ( 1964$)$. It appears as part of chapter 95 headed Racketeering. An additional federal extortion statute in its most general form makes it a crime to transmit in interstate commerce any communication containing any threat to injure the property or reputation of the addressee or of another. I8 U.S.C. $\$ 875(\mathrm{Ig64})$. Other portions of the section deal with specifics such as kidnapping.

${ }^{15}$ Hulahan v. United States, 2⿰氵4 F.2d $44 \mathrm{r}$ (8th Cir. 1954), cert. denied, 348 U.S. 856 (1954).

${ }^{40}$ I8 U.S.C. \$ I95I (I964). See Bianchi v. United States, 219 F.2d 182 (8th Cir. I955), cert. denied, 349 U.S. 915 (1955).

${ }^{17}$ United States v. Palmiotti, 254 F.2d 49r, 497 (2d Cir. I958); Callanan v. United States, 223 F.2d I7I, I78 (8th Cir. I955).

${ }^{18}$ United States v. Kennedy, 291 F.2d 457 (2d Cir. I96r).

${ }^{19}$ Senate Hearings 31, 32.

${ }^{80}$ Conference Report 29.
} 
of live witnesses to the transactions, common law exclusionary rules of evidence such as the hearsay rule rendered the prosecutor's task even more difficult. Title II attempts in a unique way to solve some of these difficulties.

\section{III}

\section{The StatuTory Framework}

\section{A. The Extortionate Credit Provisions of the CCPA}

Title II of the CCPA constitutes a custom-made legislative attack upon extortionate extensions of credit by organized crime. Findings on which the legislation is based and the purposes of the legislation are set forth in positive terms. ${ }^{51}$ Federal jurisdiction is based upon the commerce and bankruptcy clauses of the Constitution. ${ }^{62}$

\section{An "extortionate extension of credit" is defined as}

any extension of credit with respect to which it is the understanding of the creditor and the debtor at the time it is made that delay in making repayment or failure to make repayment could result in the use of violence or other criminal means to cause harm to the person, reputation, or property of any person. ${ }^{53}$

Anyone making an extortionate extension of credit or conspiring to do so is guilty of a federal crime and is to be fined not more than $\$ 10,000$ or imprisoned not more than twenty years, or both. ${ }^{54}$

In recognition of the difficulties in proving or finding witnesses to testify as to an extortionate extension of credit, Title II states that if it is shown that four facts were present in connection with an extension of credit, there is prima facie evidence that the extension of credit was extortionate, which facts, however, are nonexclusive. ${ }^{55}$ The four conditions which, if established, constitute prima facie evidence are these: $:^{50}$

(x) The repayment of the extension of credit, or the performance of any promise given in consideration thereof, would be unenforceable, through civil judicial processes against the debtor or

(A) in the jurisdiction within which the debtor, if a natural person, resided,

(B) in every jurisdiction within which the debtor, if other than a natural person, was incorporated or qualified to do business at the time the extension of credit was made.

(2) The extension of credit was made at a rate of interest in excess of an annual rate of 45 per cent ....

\footnotetext{
${ }^{61}$ CCPA $\S 201(a)$.

¿2 Id. $\S 201(\mathrm{~b})$.

${ }^{8} I d . \$ 89 \mathrm{I}(6)$.

*Id. $892(\mathrm{a})$.

o5 Id. 5892 (b).

Eo $7 d$.
} 
(3) At the time the extension of credit was made, the debtor reasonably believed that either

(A) one or more extensions of credit by the creditor had been collected or attempted to be collected by extortionate means, or the nonrepayment thereof had been punished by extortionate means or

(B) the creditor had a reputation for the use of extortionate means to collect extensions of credit or to punish the nonrepayment thereof.

(4) Upon the making of the extension of credit, the total of the extensions of credit by the creditor to the debtor then outstanding, including any unpaid interest or similar charges, exceeded \$roo.

In order to reach the higher echelons of organized crime supplying money for extortionate extensions of credit, Title II further states that whoever wilfully advances or supplies money or property to any person with reasonable grounds to believe that the person will use the money to make extortionate extensions of credit is guilty of a federal crime and shall be fined not more than \$ro,000 or an amount not exceeding twice the value of the money or property advanced, whichever is greater, or shall be imprisoned not more than twenty years, or both..$^{67}$

Participating or conspiring to participate in collections or attempts to collect credits by extortionate means constitutes a federal crime subject to a fine of not more than \$ro,000 or imprisonment of not more than twenty years, or both. ${ }^{58}$ To aid in proving the crime of collection of credits by extortionate means, Title II further provides that evidence may be introduced of other instances of collection by extortionate means or as to the reputation of the defendant. ${ }^{59}$ Also to aid in proving extortionate extensions of credit, United States attorneys are given power to require the production of books, papers, or other evidence and to make application to the court that a witness be instructed to testify or produce evidence. Upon order of the court, the witness will not be excused from testifying or producing evidence on the ground that the testimony or evidence may tend to incriminate him, in which event immunity of the witness from prosecution is provided. ${ }^{60}$

\section{B. Relationship of the UCCC to the Extortionate Credit Provisions of the CCPA}

As noted above, one of the factors constituting a basis for prima facie evidence that an extension of credit was extortionate is that the repayment of the credit would be unenforceable through judicial process against the debtor. Since all four factors must be present to establish prima facie evidence, ${ }^{61}$ unenforceability must be present. Looking at the maze of statutory provisions as to ceiling interest rates described above, it is far from clear in the great majority of states whether repay-

\footnotetext{
${ }^{87} I d . \S 893$.

${ }^{58} I d . \S 894(\mathrm{a})$.

${ }^{80} I d . \$ \$ 894(\mathrm{~b})$ and (c).

${ }^{\mathrm{B} 0} \mathrm{Id}$. $\$ 895$.

${ }^{62} I d . \$ 892(\mathrm{~b})$.
} 
ment of a credit extended by organized crime is unenforceable through judicial process. The high rates charged by organized crime would exceed maximum ceiling rates in some but by no means all cases. If the debtor were a corporation, presumably it could contract for any rate, and, theoretically at least, such a contract would be enforceable in those states in which corporations may not plead usury as a defense. ${ }^{62}$ In other cases, contracts of organized crime for exorbitant rates of interest would not be enforceable as to a portion of the interest rate contracted for but would be enforceable as to principal in almost all states and as to some interest in many states. Would these cases meet the requirement of "unenforceability"? Presumably the latter cases at least would fall within the alternative condition that "the performance of any promise given in consideration" of the extension of credit be unenforceable.

This problem would not be solved by specifying some precise rate above which credits would be unenforceable. To do so would simply reinstate the multiple general usury problems portrayed by Professor Benfield. Fortunately, Congress followed much sounder principles in the CCPA. The basic test of criminality is extortion, with a rate in excess of 45 per cent per annum being used as one of the required factors to establish prima facie evidence. Although superficially 45 per cent per annum may seem high to anyone still imbued with the myth that 6 per cent per annum is the normal legitimate rate for all types of transactions, 45 per cent is well below all rates of interest actually charged by organized crime in loan sharking activities and, hence, is a realistic and meaningful standard.

The UCCC fits nicely with the CCPA statutory scheme. Section 5.ro7(I) of the UCCC provides that extensions of credit of a kind defined as extortionate in the CCPA are unenforceable. Further, to implement the evidence problems dealt with by the CCPA, UCCC section 5.107(2) provides that if the charge exceeds 45 per cent per annum and the creditor has a reputation for using or threatening to use violence or other criminal means to cause harm to the person, reputation, or property of any person for the purpose of collecting debts, there is prima facie evidence that the extension of credit is unenforceable. Thus, with respect to the unenforceability factor of the CCPA's prima facie evidence provisions, the UCCC would substitute in a great majority of states a solid reference point of state law in place of either a vacuum or highly uncertain state law, and the combination of the two statutes would in effect eliminate the federal act's requirement of unenforceability by providing for its satisfaction by proof of factors (2) and (3)(b) in the federal formula, as stated above.

This analysis of the relationship of the UCCC to the extortionate credit provision of the CCPA suggests a recapitulation of the total statutory scheme of the UCCC with respect to rate ceilings. There are three parts to it. First, in place of

\footnotetext{
${ }^{\text {e2 }}$ Benfield, supra note $2 \mathrm{x}$, at $847-5 \mathrm{I}$.
} 
the utterly confused and almost nonsensical mass of rate ceiling provisions appearing on the statute books of the several states today, a single set of graduated rates is proposed for all consumer credit, with permitted maximum ceilings of $3^{6}$ per cent per annum on the first $\$ 300$, 21 per cent per annum on the next $\$ 700$, and 15 per cent per annum on balances over $\$ 1,000$ and with composite rates levelling off at a base ceiling rate of 18 per cent per annum; in store or sales credit and revolving credit, there is one variation from this general standard, namely, 24 per cent per annum on the first $\$ 500$ of outstanding balance and 18 per cent per annum on balances in excess of $\$ 500$.

Second, in the case of business credit, determined primarily by the organizational status of the debtor and residually by business purposes, with minor exceptions all ceilings are removed on the reasoning that organizations and most business debtors may fend for themselves in agreements as to interest rates and that maximum ceilings in the great preponderance of cases do more harm than good.

Third, insofar as any type of debtor, business or otherwise, needs protection from the genuinely vicious evils of loan sharking, the extortionate credit provisions of the CCPA, supplemented by the coordinated provisions of the UCCC, provide realistic and effective civil and criminal protection.

Thus, the combined provisions of the CCPA and the UCCC contain the potential of converting the existing chaos of rate ceilings to reasonable and realistic order, and at the same time provide meaningful and highly significant weapons to combat loan sharking by organized crime.

\section{IV}

\section{Analysis of the Evidentiary Provistons of the CCPA}

The extortionate credit transactions title of the CCPA contains the express congressional finding that "among the factors which have rendered past efforts at prosecution almost wholly ineffective has been the existence of exclusionary rules of evidence stricter than necessary for the protection of constitutional rights." ${ }^{03}$ Several sections of the act implement this finding by authorizing the admissibility of specific kinds of evidence and by allowing, as previously noted, the showing of four factors to constitute prima facie evidence of an extortionate credit transaction.

This is not the first time that dissatisfaction has been voiced with the strictures of the exclusionary rules of evidence. Professor Edmund M. Morgan's Foreword to the Model Code of Evidence sets the scene for complaints: ${ }^{64}$

The rules of evidence have been developed in myriads of cases, wherein the later judges have felt themselves bound by the doctrine of stare decisis to adhere to the pronouncements of their predecessors but bound also to avoid the absurdities which

${ }^{63} \mathrm{CCPA} \S 20 \mathrm{~T}(\mathrm{a})(2)$.

as Model Code of Evidence 5 (I942). 
the simple application of these pronouncements would produce. In attempting to escape this dilemma they have engrafted qualifications, refinements, and exceptions upon the earlier rules, so that the law of evidence has grown irregularly and in haphazard fashion, one rule seeming to have no relation in reason to another.

Historical emphasis upon the many rules for excluding from trials a great deal of relevant evidence resulted in inadequate consideration of other evidentiary problems. "Operating these [exclusionary] rules has kept judges and lawyers and law professors so fully occupied that they have not yet satisfactorily explored the important questions of evidential cogency." ${ }^{\text {"I }}$ In the CCPA, Congress begins a voyage into waters which are not completely charted. Congress has not only determined that public policy favors the admission of clearly relevant evidence but has made a judgment that certain evidence is relevant and admissible despite problems of affording a defendant an opportunity to cross-examine. The broader focus of congressional action may be better understood by an explanation of a classic exclusionary rule-the rule prohibiting admission of hearsay evidence.

Hearsay may be defined as an extrajudicial statement offered to prove the truth of the matters asserted in the statement. ${ }^{66}$ Judges have offered various reasons for this exclusion including absence of an oath. Today the most commonly stated ground for exclusion is the absence of opportunity for cross-examination. Dissatisfaction with application of the hearsay rule has been and is widespread. From the limited exceptions of the r8oos, the common law has developed numerous varieties of exceptions, eighteen by one count. ${ }^{67}$

In addition to the judicial lawmaking, legislatures have created numerous exceptions, some narrow in scope, some rather sweeping. The Model Code of Evidence, for example, provides for the admissibility of hearsay declarations made by a third person on personal knowledge if the third person is unavailable as a witness or is present and subject to cross-examination. ${ }^{68}$ The approach of the Uniform Rules of Evidence is to define hearsay, make it inadmissible, and then list thirty-one exceptions. ${ }^{6 \theta}$ The patchwork result of the current law has been characterized as "a series of somewhat inconsistent compromises between free admissibility of relevant information and exclusion of information dangerous because it may be overvalued by the trier. ${ }^{370}$

In several instances the draftsmen of the CCPA have made a determination that there is a rational connection between two facts and that one is relevant to prove the existence of the other. For example, the CCPA authorizes the trial court in its

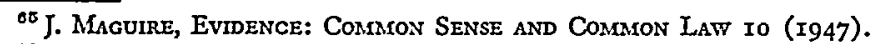

00 5 J. Wigmore, Treatise on Evidence $\$ 136 \mathrm{I}$ (3d ed. I940) [hereinafter cited as Wigmore].

${ }^{\circ 7}$ Model CODE of Evidence 38 (1942).

${ }^{\text {as }}$ Id., rule 503 .

${ }^{00}$ Uniform Rules of Evidence, rule 63.

${ }^{70}$ Weinstein, Some Difficulties in Devising Rules for Determining Truth in Judicial Trials, 66 Colum. L. REv. 223, 244 (1966).
} 
discretion to admit evidence of the defendant's reputation for using extortionate means of collection on the issue of the understanding of the debtor and creditor at the time of the transaction in issue; such evidence raises problems of hearsay. In addition, a prior similar act of collection by extortionate means known to the victim may be introduced to show an implicit threat in a charge of extortionate collection. Reputation evidence may be admitted under certain conditions to show that a communication carried an express or implied threat. These determinations involve considerations somewhat different from those involved in authorizing the admissibility of facts which admittedly have a rational connection to issues in a case but which have traditionally been excluded as hearsay. The act also confers a special status on proof of certain factors and allows their showing to be prima facie evidence of an extortionate credit transaction. We will examine these provisions in detail.

\section{A. Similar Prior Act of Extortion}

Section 894 of the CCPA deals with the collection of credits by extortionate means. As previously noted, the act has defined "extortionate means" to include any means which involves the implicit threat of use of violence or other criminal means to cause harm to the person, reputation, or property of any person. ${ }^{71}$ To prove this implicit threat the prosecutor is allowed to introduce evidence "tending to show that one or more extensions of credit by the creditor were, to the knowledge of the person against whom the implicit threat was alleged to have been made, collected or attempted to be collected by extortionate means." ${ }^{\text {.72 }}$ The prosecutor, therefore, may introduce one different extortionate collection with another victim as evidence that the extortionate collection charged had been implicitly threatened if he can show that the prior act was known to the victim of the charged extortion.

The Conference Report states that "Section 894 (b) merely codifies a principle of evidence which already appears to be recognized in the case law ... [so as] to leave no doubt whatever as to its applicability." out that where the doing of an act is to be proved there can never be a direct inference from a prior act to the act charged. There must be an intermediate step." "A may do the act once and may never do it again; and not only may he not do it again, but it is in no degree probable that he will do it again."75 The usual procedure is to infer from the past act the defendant's character or some other human quality and infer from that character or quality that it led to the act charged.

As applied to a criminal case, a prosecutor might argue that the prior extortionate

${ }^{71} \mathrm{CCPA} \S 89 \mathrm{I}(7)$.

${ }^{72} I d . \$ 894$ (b).

${ }^{73}$ CONFERENCE Report 30.

"7 I WIGMORE $₫$ I92.

${ }^{75}$ Id. 
collection or attempt evidences a character or propensity to commit the crime charged. Wigmore points out that the law here declares a general and absolute rule of exclusion. ${ }^{76}$ The basis for the exclusion is not put on the basis of lack of probative value but on the ground that the jury may give excessive weight to the prior particular acts. There is also the problem of giving a defendant sufficient notice of the charge so that he can have an opportunity to defend himself. ${ }^{77}$

In the CCPA Congress has authorized the introduction of a similar act on the issue of an implicit threat. It is clear that if there is a rational connection between the prior extortionate act and the threat charged, the similar act is not necessarily inadmissible merely because it tends to prove criminal disposition or propensity and would be inadmissible for that purpose. ${ }^{78}$ Evidence of past crimes

will be admitted where there is a real reason for its reception other than the inference of one crime from the perpetration of another; when the evidence of the other crime is offered to show (I) motive, (2) intent, (3) identity, (4) absence of mistake, (5) a common scheme or plan, (6) means of accomplishing the crime charged. ${ }^{9}$

The question, therefore, would seem to be whether the implied threat which the prior similar act is offered to prove is evidence of the intent of the defendant and therefore admissible under a well-recognized exception, or whether it is evidence of the act itself and therefore inadmissible. The peculiar feature of this kind of evidence is that the act itself is assumed to have taken place. It is the intent with which the act is done that is in issue and the prior doing of another similar act helps reduce the possibility that the act in question was innocently performed. ${ }^{80}$ In a case under the Hobbs Act, ${ }^{81}$ the prosecution was allowed to introduce in rebuttal the testimony of similar extortions by the defendant which occurred after the offense charged. The court recited the general rule, noted the exceptions, and held that "evidence of other offenses may be received if relevant for any purpose other than to show a mere propensity or disposition on the part of the defendant to commit the crime." 82 The court held that admissibility of a subsequent extortionate act was in the discretion of the court and "relevant to explain [the defendant's] purpose or intent in soliciting money from [the victim]." case, the court had ruled in similar fashion: "Since it was the [defendant's] testimony that he had obtained the money without any threats, we think the evidence was

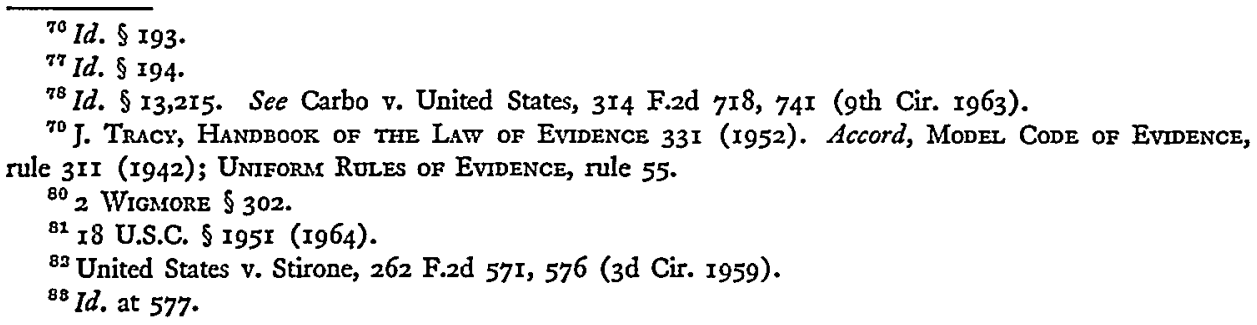


properly received for its probative effect on the issue of [his] intent in taking the money." 84

Similarly, in extortionate collection cases under the CCPA an issue will be whether the defendant obtained or tried to obtain money from the victim by the use of threats. By analogy to those federal cases, the manner of obtaining of money, i.e., by threats or otherwise, can be equated with intent, and the prior extortionate act should be admissible on well-settled principles. It should make no difference that the prior act is offered as part of the prosecutor's direct case rather than in rebuttal..$^{85}$

\section{B. Use of Reputation Evidence}

The extortionate credit transactions title of the CCPA has several references to the use of reputation evidence. A prosecutor may show the reasonable belief of the debtor that the creditor had a reputation for the use of extortionate means to collect extensions of credit. This showing establishes one of the four factors which together constitute prima facie evidence of an extortionate credit extension. Admissibility of evidence as to a victim's state of mind or, as phrased in the act, reasonable belief has been repeatedly upheld in extortion cases: "Proof of the state of mind of the victim is relevant, indeed essential, to a prosecution for extortion, and this may be evidenced by the victim's own testimony at the trial ...."

The Congress, however, went much further in authorizing the use of reputation evidence. The section on making extortionate credit extensions provides that if there is evidence tending to show the unenforceability of repayment of the credit extension, as previously discussed, and a rate of interest in excess of 45 per cent, the court in its discretion may allow evidence tending to show the reputation as to collection practices of the creditor in the debtor's community. This evidence is admitted for the purpose of showing the understanding of the debtor and creditor at the time of the extension of credit if direct evidence of the actual belief of the debtor as to the creditor's collection practices is not available. ${ }^{87}$ A similar provision appears in the section prohibiting collection of credits by extortionate means, under which section the general reputation of the defendant is admissible, in the discretion of the court, for the purpose of showing that words or other means of communication shown to have been employed as a means of collection in fact carry the express or implicit threat.

The use of such evidence obviously raises serious problems. The starting point in an analysis is that reputation used to prove the character of a defendant is hearsay. Reputation is distinguished from the character reputed and "is the expression of an opinion on the part of the community, used testimonially, but uttered out of Court

\footnotetext{
84 United States v. Blount, 229 F.2d 669, 672 (2d Cir. 1956).

${ }^{88}$ See United States v. Palmiotti, 254 F.2d 49r, 497 (2d Cir. I958).

${ }^{86}$ United States v. Kennedy, $29 \mathrm{I}$ F.2d 457, 458 (2d Cir. I96I).

${ }^{87}$ CCPA $\$ 892(c)$.
} 
and not under cross-examination." 88 As previously discussed in connection with the use of similar prior acts of extortion, the character of an accused or his propensity to commit the crime charged is excluded in criminal cases at least until put in issue by the accused. If offered on the issue of character, such evidence would not only raise the problems of undue prejudice and lack of notice previously discussed but in addition would raise questions as to whether such evidence violates the defendant's constitutional right to confront witnesses and cross-examine them. ${ }^{89}$

Obviously the community cannot be cross-examined. A similar question is therefore raised by the use of reputation to prove the understanding of the creditor and debtor-that is to say, the state of mind of each of them-and the state of mind of the debtor with respect to whether a communication carried an express or implied threat. Since the use of this evidence requires a preliminary showing that direct evidence of the actual belief of the debtor as to the creditor's collection practices is not available, the question arises whether the creditor-defendant would be denied a constitutional right to cross-examine an absent debtor. The conference report has the following comment on the use of such evidence: $:^{00}$

The ban on reputation evidence as part of the prosecution's case in chief has never been absolute, and where, as here, it is directly relevant to the state of mind of the parties in entering into the transaction, there will undoubtedly arise cases where it should very properly be before the trier of facts.

One instance of the use of reputation evidence as part of the prosecution's direct case is found in the situation where prosecution offers the reputation of an "enforcer" to show that the reputation was used by the defendant to instill fear in the victim "as a dangerous weapon to be used to strike fear into the hearts of [the victims]."11 This differs from the use to which the drafters of the CCPA are putting reputation evidence. Nevertheless, analysis of both the constitutional objections and the hearsay problem depends on the drawing of careful distinctions. The hearsay rule forbids the use of extrajudicial utterances as an assertion to evidence the fact asserted. "What the hearsay rule forbids . . . is the use of testimonial evidence-i.e. assertions-uttered not under cross-examination." ${ }^{\text {92 }}$

Wigmore notes that the hearsay rule is not applicable to the use of the utterance as circumstantial evidence. Circumstantial evidence is "that evidence which tends to prove a disputed fact, by proof of other facts which have a legitimate tendency to lead the mind to a conclusion that the fact exists which is sought to be established."13 Wigmore goes on to point out that wherever the utterance is offered on the state of mind which ensued in another person in consequence of the utterance,

\footnotetext{
${ }^{88} 5$ WIGMORE $\$$ I 609 .

${ }^{80}$ Pointer v. Texas, 380 U.S. 400 (1965); Douglas v. Alabama, 380 U.S. 415 (1965).

${ }^{\circ 0}$ Conference Report 29.

${ }^{01}$ Carbo v. United States, 3I4 F.2d 718, 74I (9th Cir. 1963).

D2 6 WIGMORE $\S$ I788.

${ }^{03}$ Rumely v. United States, 293 F. 532, 55r (2d Cir. 1923), cert. denied, 263 U.S. 7r3 (1923).
} 
the hearsay rule is not violated. He states, "On this principle the hearsay rule interposes no obstacle to the use of letters, notices, oral information, reputation or any other form of verbal utterances by one person, as circumstantial evidence that another person had knowledge or belief as to [various facts]."

Analysis of the leading case supporting the confrontation rule ${ }^{95}$ does not negative this conclusion. In that case the chief government witness at a preliminary hearing was the victim of a robbery who identified the defendant as the gunman. At the trial of the defendant for robbery, this principal witness was unavailable, and the prosecution put in evidence a transcript of the testimony of the witness at the preliminary hearing. On appeal the Supreme Court reversed on the ground that the testimony at the preliminary hearing had not been taken at a time and under circumstances permitting cross-examination by defendant's counsel. However, in its opinion the Court noted that dying declarations and testimony of a deceased witness taken in a former trial had been ruled admissible, and the Court took pains to point out that it was not overruling these cases, expressly stating, "There are other analogous situations which might not fall within the scope of the constitutional rule requiring confrontation of witnesses." Clearly, inadmissibility of the transcript of the testimony of the victim of a robbery identifying the defendant, which victim witness was not cross-examined at the preliminary hearing and was not present at the trial when his transcript was offered, would not preclude the use of all circumstantial evidence by the prosecution to identify the defendant as the robber-for example, evidence tracing to the defendant ownership of a gun used in the robbery.

Under this analysis the use of reputation evidence does not contravene constitutional requirements of witness confrontation since it is not being used as a testimonial utterance which should be subject to cross-examination. Reputation evidence like other forms of circumstantial evidence may be used to establish a fact-namely, the state of mind of the victim-and should be admitted just as other forms of circumstantial evidence are admitted in criminal cases. The question as to circumstantial evidence is whether there is a rational connection between the basic fact of reputation and the inference of the victim's state of mind. Congress has, in effect, declared that, in the absence of direct evidence, a victim may reasonably be found by a jury to have known the reputation of one who loaned him money at more than 45 per cent.

This analysis is strengthened because the admissibility of such evidence lies in the discretion of the trial court and can be excluded if undue prejudice to the defendant would result from its admission. As Judge Hand stated in commenting on the use of similar crime evidence, the question is always

\footnotetext{
${ }^{04} 6$ Wigmore $\$ 1789$ (emphasis added).

${ }^{95}$ Pointer v. Texas, 380 U.S. 400 (1965).
} 
whether it is likely, all things considered, to advance the search for truth; and that does not inevitably follow from the fact that it is rationally relevant. . . . [T] he question is always whether what it will contribute rationally to a solution is more than matched by its possibilities of confusion and surprise, by the length of time and the expense it will involve, and by the chance that it will divert the jury from the facts which should control their verdict. ${ }^{96}$

If the court balances these considerations in favor of admission, the jury should be allowed to draw the inference stated in the statute.

\section{Prima Facie Evidence}

Section 892(b) of the CCPA provides that if certain factors are present in connection with the extension of credit, there is prima facie evidence that the extension of credit is extortionate. The four factors, which have previously been discussed, are these: $(a)$ the inability of the creditor to obtain a personal judgment for the full debt against the debtor, (b) a 45 per cent per annum interest rate, $(c)$ a reasonable belief on the part of the debtor that the creditor had used extortionate means to collect other extensions of credit or had such a reputation, and (d) a minimum $\$ 100$ amount.

The phrase "prima facie evidence" has been used in many senses. ${ }^{97}$ Wigmore points out that the term has been used in two senses. First, in connection with presumptions, the term is sometimes used as equivalent to the notion of putting upon the opponent the duty of producing evidence. The second sense of the phrase is where the proponent having the duty of producing evidence in order to get to the jury is deemed to have fulfilled that duty so that he is no longer liable to a directed verdict. ${ }^{08}$ The conference report indicates that Congress intended the latter sense of "prima facie case." The report states, ${ }^{\text {99 }}$

It is intended that the inference created by the presence of the factors set forth in $\$ 892$ (b) may be weighed by the jury as evidence. It is not a mere rebuttable presumption and is not to be treated under the rule adopted in some jurisdictions with respect to such presumptions, which are said to be wholly dispelled by the introduction of any direct evidence.

Some writers and courts have used the phrase "prima facie evidence" in the sense that it combines the effect of a classic presumption and an inference. ${ }^{100}$ A classic presumption is defined as a procedural rule requiring a court, once it concludes that a "basic fact" is established, to assume the existence of a "presumed fact" until certain conditions are met-that is, evidence to the contrary is introduced and the presumption is destroyed. ${ }^{101}$ If, in the absence of other evidence, a showing of the

\footnotetext{
${ }^{06}$ United States v. Krulewitch, I45 F.2d 76, 80 (2d Cir. ז944).

${ }^{07}$ See R. Field \& B. Kaplan, Civil Procedure 446-48 (temp. 2d ed. I968).

${ }^{03} 9$ WIGMORE $§ 2494$.

${ }^{\circ 0}$ Conference Report 29.

${ }^{200}$ See Hobart-Farrell Plumbing \& Heating Co. v. Klayman, 302 Mass. 508, I9 N.E.2d 805 (1939).

101 See Model Code of Evidence, rule 702 et seq. (1942).
} 
four factors were held to compel a jury to find that an extortionate credit transaction existed, constitutional problems would arise. These problems could be avoided by interpreting the act to provide that a continuing inference of the use of extortionate means may be made by a jury from the four factors even though conflicting evidence is introduced. The conference report recites that there is sufficient rational connection between the four factors and the inference of the use of extortionate means to make it "constitutionally permissible" to put the burden on the defendant to come forward with evidence to show the innocent nature of the transaction, if this was the case. ${ }^{102}$ This burden should be limited to a burden on the defendant if he wishes to better his position with the jury. No shifting of the ultimate burden of proof is stated or should be implied.

This interpretation is consistent with that of other statutes where the word presumption is expressly used. For example, in narcotics prosecutions under $2 \mathrm{I}$ U.S.C. $\$ 174$ it is provided that possession of narcotics raises a presumption of violation. The federal courts have held that there is no classic presumption of participation in the crime arising from possession of the fruits of the crime in the sense that conviction is commanded but rather that an inference by the jury of participation is permissible and therefore conviction is permissible. The burden of going forward is shifted so that the case goes to the jury, but the finding of possession does not require the jury to convict even in the absence of contradictory evidence. ${ }^{103}$

Of course, there are still constitutional difficulties as exemplified in the leading case on presumptions, Tot v. United States. ${ }^{104}$ There the Supreme Court invalidated a statute which made it unlawful for a convict to receive firearms shipped in interstate commerce and which provided that possession of firearms created a presumption that the firearms were received in violation of the act. The Court held that "a statutory presumption cannot be sustained if there be no rational connection between the fact proved and the ultimate fact presumed, if the inference of the one from proof of the other is arbitrary because of lack of connection between the two in common experience."105

In light of Tot, the question of the propriety of constituting the four factors as prima facie evidence depends on the logical connection between those factors and the ultimate fact that the extension of credit is extortionate. The conference report points out that in an arm's-length transaction "people simply do not lend sums of money at exorbitant rates of interest under circumstances where they cannot legally enforce the obligation to repay." 108 Where the required additional factor of the victim's state of mind is shown either by direct testimony or by the circumstantial

\footnotetext{
${ }^{102}$ Conference Report 29.

${ }^{103}$ Wilson v. United States, 162 U.S. 613, 619-20 (I896); Bollenbach v. United States, 326 U.S. 607 (I946).

106 3 I9 U.S. 463 (1943).

${ }^{305}$ Id. at $467-68$.

${ }^{100}$ Conference Report 29.
} 
evidence discussed above, the inference of extortion is rational and constitutionally permissible.

\section{Conclusion}

Extortionate extensions of credit by organized crime constitute a growing cancer in American society. The CCPA provisions on this subject offer a strong new weapon to combat this malignant growth. They confer jurisdiction on the federal government and deal intelligently with the subject matter involved. In provisions on evidentiary matters, some ventures beyond existing law are tried. However, the ventures are not extreme, there is rationale and authority to support them, and the evil to be met justifies the statutory authorizations provided.

Somewhat by historical coincidence the UCCC effectively deals with one of the basic elements of extortionate extensions of credit, namely the underlying law as to what interest rates are proper. Further, the UCCC specifically provides related language and concepts. ${ }^{107}$ Therefore, the UCCC nicely complements the new federal provisions. In doing so, it provides a somewhat accidental but, at the same time, major benefit to American society and to both federal and state law on which that society necessarily rests.

\footnotetext{
${ }^{107}$ UCCC $\$ 5.107$.
} 
